\title{
Lessons Learned in Building Cross-Disciplinary Partnerships in Entrepreneurship Education through Integrated Product Development (IPD)
}

\author{
John B Ochs, Mechanical Engineering \& Mechanics, Lehigh University, Bethlehem, PA \\ Todd W Watkins, Economics, Lehigh University, Bethlehem, PA \\ Drew Snyder, Art \& Architecture, Lehigh University, Bethlehem, PA
}

\begin{abstract}
Since 1994 a team of Lehigh faculty have been developing and implementing a multi-disciplinary educational environment to enable undergraduates and graduate students to experience the challenges and creative exhilaration of technical entrepreneurship through new product development. Lehigh's Integrated Product Development (IPD) program provides a campus focus for cross-disciplinary collaboration. With top-level administrative support, additional degree programs are under development. These include Integrated Business and Engineering, Computer Science and Engineering, Design Arts, Masters of Business Administration and Engineering and an entrepreneurial ventures track in the MBA program. Through planning, trial and error and (now) a formal comprehensive assessment process, the IPD faculty team has developed basic lessons learned from this curricula development experience. These lessons and the skills needed to succeed closely mimics those learned in any new venture process, with the caveat that colleges and universities are unique organizations with unique incentive, organizational and individual behavior issues. The categories of lessons learned include: vision and mission, customer focus, teaming, interpersonal relationships, leadership, resource development and allocations, recognition and rewards, infrastructure development, managing curricula development and managing a constantly changing administration.
\end{abstract}

\section{Introduction}

The need for cross-disciplinary teams for new product development has been well studied and documented [Ref 1-7]. Over the past ten years the need for students to experience new product development and in particular, to experience cross-disciplinary teaming has made its way into accreditation criterion for engineering, business and even arts and science. College recruiters are constantly asking our students "Have you worked in teams?" "Has it been a successful experience?" "What team building and leadership skills have you developed?"

Lehigh students enrolled in our Integrated Product Development (IPD) courses are fortunate to have this experience while undergraduates. Recruiters have stated that each year the students in Lehigh's IPD program are "the best prepared in this class of recruits." In addition our student report to us that the job interview itself often focused on the results on their year-long IPD project. This is not by happenstance, but by design and planning.

The IPD projects has been designed to give students industrial experience in new product development as well as the opportunity to work in a truly cross-disciplinary team. Ideally these teams are made up of students from engineering, business and design arts. This cross-disciplinary approach has evolved over the past seven years and for the upcoming year 2003 projects, there will be 203 students from 24 majors in 33 teams working with 19 companies on a variety of 
projects. With this wealth of project experience, we have developed a classification scheme for companies and projects. Project can be classified as 1) R\&D projects, 2) new to the market projects, 3) products that are new to the company, 4) product line extensions or product improvement projects, 5) manufacturing process improvement, 6) Manufacturing equipment improvement.

Over the past 7 years and throughout many of the year-long projects, we have experienced companies in many different situations including on the down side company buy-outs, company bankruptcies, severe downturns in business, death and divorce of company owners, law suits in which we were named as defendants. On the ups side we have witnessed company start-ups, initial placement offers, mergers and companies involved in exponential growth. Understanding the current position of the company, local, regional and the overall economy are important to project success. The projects themselves can also be classified and organized in terms of resources - money, people and expertise needed. Finally, understanding our own institution, college and department and its current position in organizational, local and regional economics is necessary and particularly important as the program matures and you are start to seek permanent funding.

\section{Overview of Lehigh's IPD Program}

As we have developed our own program, we have realized that there are many similarities between new product development process and our own process for developing the IPD program. The process involves the following: 1) development of an implementation team, 2) planning, 3) developing alternative program designs, 4) selecting the best design that fit our needs, 5) developing pilots to prove the concept and legitimize costs, 6) developing a plan to ramp up, 7) secure resources to implement the ramp up, 8) starting the full-blown program, measuring results and continuously improving it. For this overall process and for each of these steps there are lessons learned as well as strategies developed, tried, refined, retried and retried again until they worked within our unique and often changing educational environment.

\section{Developing a cross-disciplinary faculty team}

At various stages of development Lehigh's IPD have been fortunate to attract high quality faculty from various departments from across campus. These faculty members are kindred spirits who were not happy with the status quo, who wanted to improve their own department or major, who were willing to take risks and who were looking for outlets for their creativity. Again, we were lucky that most department chairs encouraged and rewarded faculty for participating in IPD.

The core faculty group found common ground in their collective interest in engineering design, entrepreneurship and teamwork. However, even this was not without false starts. In fact, we spent two years in committee with a group "interested" faculty who argued over the definition of the word 'design.' What we discovered is that we need a group of faculty who are not only "interested" but action oriented as well.

The make up of the IPD Implementation committee was at first dominated by mechanical engineering faculty. This has since evened out with the addition of business faculty and more recently, design faculty. The makeup of the faculty team has been fluid with people coming on 
and off as needed. The individuals on the team have to develop mutual trust, a common vision, goals and share in rewards. Finding the right people to work in a team for a long period of time is probably the most difficult task of the implementation steps. This is particularly true when you consider that Universities are the last bastion for "Lone Ranger" type of individual: fiercely independent, often isolated, distrustful but usually highly principled.

In order to find the right faculty you can try anything. Talk to department chairs about your need to collaborate, followed by one-on-one conversations with potential partners. For example at one point in the IPD start up, pairs of faculty went to each and every university department in the College of Arts and Science to make a pitch for faculty to join in the program development. Another method we tried was to read each faculty profile in the university catalog looking for business faculty with engineering background, or engineering faculty who started their own businesses. If you are told to avoid certain faculty, go talk to them yourself, anyway. In our experience, we had a department chair actually try to hide a young faculty member from us. This faculty member turned out to be a true leader of the IPD effort in the College of Arts and Science.

In order to keep faculty from across campus involved in your cross-disciplinary program, you must develop mutually beneficial relationships based on openness and complete trust. For us this means openness in budgets and finances and the potential for recognition and rewards for everyone who contributes. The rewards do not have to be financial. It can be letters of support at the annual review, nominations for awards, opportunities to lead, opportunities for consulting, sharing with all participants the opportunity for grants, gifts and research funding.

In developing an academic program, it is very important to protect younger faculty. At researchoriented institutions we would recommend only including tenured faculty to be part of an implementation team for an academic program. Interested untenured assistant professors should be advised to focus on establishing research in this area and develop relationships with funding sources. Tenured faculty should be protected from overloads. Many energetic faculty are coerced into teaching interesting course "on the margins." While this is fine for one-time pilots, it is not sustainable. The faculty team must get continuing commitment from academic department chairs and deans to support faculty involvement in cross-disciplinary programs as part of their normal annual teaching load.

\section{Planning}

The first action item of the faculty committee is a plan with timeline. The plan includes developing 1) a vision, 2) goals to be accomplished, 3) program components, 4) evaluation strategies and metrics. Figure 1 shows the result of our planning in a graphical form. This figure is a visual consensus-generating tool where the timeline goes from top to bottom. We have used this method often and with great success for this and other projects.

The timeline in a university setting is another interesting issue. University faculty measure time in semesters or quarters, not man hours as is done in industry. Regardless of the scope on the scope of your vision, if you are trying to change curricula, it is going to take years. For example, Lehigh Integrated Business and Engineering program received top down financial support and 
Vision

Goals

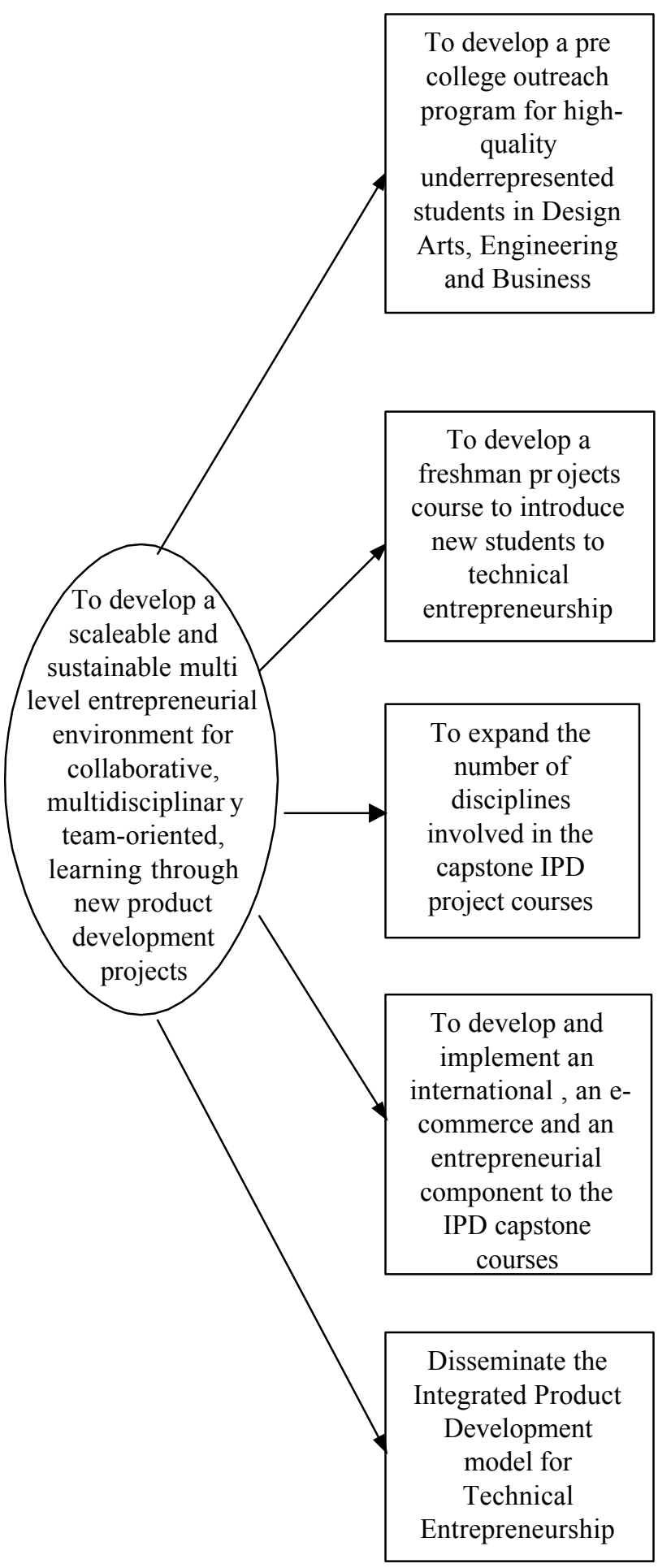

\section{Program} Components

- Coordina te with Iacocca Institute to lay ground work for programs

- Implement a Career Awareness Programs (CAP) in Design Arts, Engineering following Accounting model

- Develop other outreach activities

- Develop sustainable support

- Run pilot freshman courses

- Refine materials based on feedback

- Determine scalability

- Develop sustainable support

- Develop business college participants

- Develop engin eering college participants

- Develop Design Arts curriculum

- Develop sustainable support

- Participate in Iacocca Institute's Global village

- Determine which aspects are transferable to undergraduate curriculum

- Integrate these aspects

- Determine "product" definition in ter ms of information technology

- Establish web-based courses

- Define and implement a technical entrepreneurship component

- Develop sustainable support

- Participate in NCIIA workshop and conferences

- Present paper to ASEE and participate in others professional organizat ions

\section{Evaluation Mechanisms}

- Document the num ber of applications, participants in CAP and eventual applications to LU

- Number of other outreach programs and impact

○ Quantify permanent support dollars and staff.

- Number of student and faculty participants

- Faculty/students feedback on adapted curriculum

- Document implementation process

- Assess long-term impact on the institutions

- Number of departments requiring IPD courses

- Number of departments requiring experiential learning

- Number of new course

- Quantify permanent support dollars and sta ff

- Frequency with which web pages are uses

- Feedback from part icipants on effectiveness of tools

- Feedback on user interface and effectiveness of website

- Number of IT projects

- Number of entrepreneurial Projects

- Quantify permanent support dollars and staff

- Number of attendees at workshop

- Number of papers presented

- Number of follow up contacts

Figure 1. Evaluation Plan for IPD Model of Technical Entrepreneurship 
encouragement from the president and provost. Nevertheless, it took one and one half years to design, one half year to pilot and advertise to fill the first class and then four years to implement and graduate its first majors; a total of six years from inception to steady state. Any plan, particularly one for a multi-year project, must be both fundamentally sound and flexible to change with circumstances. Often over the past years as university administration and leadership has changed, we have had to remain focused on the key points of the IPD program: 1) providing a strategically differentiating experience for our students, 2) implementing program components that are scalable and sustainable. The differentiating experience should consistently be the answer to the question "Why should a student pick Lehigh?" Scalable means that the program can continue to grow at $20 \%$ per year and the ways and means to manage this growth. Sustainable in our context means that the courses are built into the curriculum and the resources to support it will be available.

\section{Defining success and appropriate measures}

The approach taken by the faculty team is to develop a comprehensive entrepreneurial environment starting from pre-college outreach going through graduate programs across as many disciplines as want to become involved. The program components of this environment are listed in Figure 1 and are described in detail in References 9 though 15.

A key part of the planning process is defining what we mean by success and determining the measures of success. Again, developing a concise definition over time helps keep the focus.

Defining success by focusing on the student experience: Having our students gain industrial experience, following the IPD process, working on a variety of projects and for a variety of companies, overcoming the obstacles, developing solutions and delivering the results in a professional manner - on time and on budget - while working in the structure of a cross disciplinary team.

We continue to develop ways to manage our growth and measure our success. We have semi annual internal reviews of our program components and methods by students, faculty, staff and industrial sponsors. We are developing rubrics for consistency across a variety of projects, companies and faculty advisors. Table 1 shows an example of a rubric for teaming and Table 2 shows one for overall program evaluation. Faculty, staff, students and industry sponsors are encouraged to provide feedback throughout the year on ways to improve the program.

\section{Developing alternative designs, pilot the approach}

One of the main features of our approach is searching for alternate design. Universities often suffer from NIH syndrome - not invented here, or worse, not invented by me. We have always tried to explore the world for best-in-class approaches investigating schools in the US and abroad. Many times the best approach has to be developed to fit the local conditions or constraints. The lesson learned here is to be flexible, explore all possible alternatives and select what you think will work the best with as large a number of inputs as is practical. In the end you must choose one to try. Set limits on the time to design and then test your approach with a pilot course. Have the 
pilot address the perceived weakness in your programs. For example over the past 4 years we have piloted 36 new courses to improve our new design arts program.

\section{Engaging University management}

One of the first lessons to be learned is that most educational institutions are run by the golden rule: "he (or she) who has the gold, rules." If you are not willing to take an administrative position to control resource distribution, then your job is to make the department chairs, the dean, provost and president look good. In contrast, to my knowledge, no one has ever succeeded with a program by making a dean (provost or president) look bad. Another concept to learn is the position of being "dead right" "Yes, you are right, your program would be great for our faculty and the students, but I am going to fund this other program instead." The goal should be to look for ways to get what you both want. This often happens only with extended dialog.

Since the program will take years and the administration is bound to change, engaging the new administrator can be a time consuming and constant activity. For example since 1995, the IPD program has dealt with 3 university presidents, four provosts, and since it involves three colleges (engineering, business and arts and science), there have been seven different deans.

\section{Industrial Advisory Committee}

In addition to providing outside evaluation of the program, an industrial advisory committee of influential alumni can provide stability during the times of administrative changes. This is particularly useful during program start up, which may take several years. Our industrial advisors consisted of thirteen alumni with at least one being a member of the university board of trustees. This committee met at least once each year where we reported on our progress and asked for their support in representing the program to the new administration. In addition since we were building and renovating a new facility, this committee helped the university development office raised over $\$ 4.4 \mathrm{M}$.

\section{Continuous Improvement and Role of outside evaluators}

We recommend that you adopt an attitude of continuous improvement. For us that means find the weakest part of the program and improve it, find the next and improve it and so on. In order to do this, you have to be self-critical. Hiring an outside evaluator is a best way we know to remain objective and self critical.

\section{External funding was the key}

University administrators, like most managers, are risk adverse. People look for confirmation that they are making the right decision, investing resources in the right program. For Lehigh's IPD program, an alumnus got us started with the first seed gift of $\$ 100,000$. Over the next two years we were able to get federal grants totaling $\$ 1.2 \mathrm{M}$. Over the following four year period, we have raised $\$ 4.4 \mathrm{M}$ for capital improvements and finally, with a three-year phase in, we have commitments from the deans for $\$ 500,000$ for annual operating budgets. In our environment the reverse of these steps to securing sustainable funding, rarely happens. 


\begin{tabular}{|c|c|c|c|c|}
\hline 1 & $\begin{array}{l}\text { Technical Contribution } \\
\text { Individual offered very little sound } \\
\text { and useful technical guidance } \\
\text { toward the project. Quality of work } \\
\text { done by individual was generally } \\
\text { unsatisfactory and had to be revised } \\
\text { regularly by other team members. }\end{array}$ & $\begin{array}{l}\text { Contribution to Workload / Resourcefulness } \\
\text { Individual did not take initiative or make } \\
\text { much effort in tackling a fair share of the } \\
\text { workload. Individual was often complacent } \\
\text { to let others do the majority of the required } \\
\text { work. }\end{array}$ & $\begin{array}{l}\text { Leadership \& Team Work } \\
\text { Individual did not assume a role of leadership in } \\
\text { any aspect of the project. Individual resigned to } \\
\text { following along with the general consensus of } \\
\text { the group in both technical and planning issues. } \\
\text { (or) Individual's contribution to the team was } \\
\text { counterproductive. }\end{array}$ & $\begin{array}{l}\text { Professionalism \& Interaction with Sponsor } \\
\text { Individual's level of professionalism and } \\
\text { maturity in interacting with the project sponsor, } \\
\text { team members, faculty, IPD staff, or others was } \\
\text { unsatisfactory. Individual's ability to } \\
\text { communicate effectively, professionally, or } \\
\text { appropriately with those mentioned above or } \\
\text { outside contacts for research detracted from } \\
\text { his/her ability to carry out necessary } \\
\text { responsibilities. }\end{array}$ \\
\hline 2 & $\begin{array}{l}\text { Individual's overall contribution was } \\
\text { somewhat limited (less than other } \\
\text { team members') in either relative } \\
\text { quantity or quality. (or) Individual } \\
\text { often dwelled on issues which } \\
\text { deviated from a relevant and focused } \\
\text { solution. }\end{array}$ & $\begin{array}{l}\text { Individual followed through with his/her } \\
\text { agreed upon share of the workload, but often } \\
\text { by either doing just the minimum for } \\
\text { satisfactory quality or regularly completing } \\
\text { assigned work late. (or) Amount of work } \\
\text { individual handled was not enough. }\end{array}$ & $\begin{array}{l}\text { Individual reluctantly accepted assuming } \\
\text { leadership in minor aspects of the project. (or) } \\
\text { Individual's ability to lead the group on any } \\
\text { level was either not highly efficient or not highly } \\
\text { effective. (or) Individual's interaction with the } \\
\text { team did not contribute significantly toward the } \\
\text { team's success. }\end{array}$ & $\begin{array}{l}\text { Individual's level of professionalism and } \\
\text { maturity was satisfactory. Individual's } \\
\text { confidence level in interacting with others } \\
\text { outside the team may have slightly limited } \\
\text { his/her success in carrying out responsibilities. }\end{array}$ \\
\hline 3 & $\begin{array}{l}\text { Individual's technical contribution } \\
\text { was satisfactory or better and at least } \\
\text { in line with that of other team } \\
\text { members. Individual contributed at } \\
\text { least some useful original thought } \\
\text { and technical guidance for the } \\
\text { project. }\end{array}$ & $\begin{array}{l}\text { Individual carried out his or her agreed upon } \\
\text { portion of the work well and on time. } \\
\text { Individual exhibited initiative and ingenuity } \\
\text { in his or her work. }\end{array}$ & $\begin{array}{l}\text { Individual willingly took on a leadership role } \\
\text { and did so efficiently and effectively. } \\
\text { Individual's interaction with the team was } \\
\text { positive and contributed significantly toward the } \\
\text { team's success. }\end{array}$ & $\begin{array}{l}\text { Individual's level of professionalism and } \\
\text { maturity was satisfactory. Individual's } \\
\text { confidence level in interacting with others } \\
\text { outside the team was more than satisfactory for } \\
\text { the individual to effectively handle his/her } \\
\text { responsibilities. }\end{array}$ \\
\hline 4 & $\begin{array}{l}\text { Individual's technical contribution } \\
\text { set and maintained the course of the } \\
\text { project. Amount and quality of } \\
\text { contributed work was excellent and/ } \\
\text { or significantly above that of other } \\
\text { team members. }\end{array}$ & $\begin{array}{l}\text { Individual carried out his or her agreed upon } \\
\text { portion of the work well and on time. } \\
\text { Individual took on a disproportionately large } \\
\text { portion of work \& should be credited } \\
\text { accordingly. }\end{array}$ & $\begin{array}{l}\text { Individual inspired the vision of the team, } \\
\text { nurtured a team harmony, and took on a role as } \\
\text { a natural leader. Individual's ability to guide the } \\
\text { progress of the project and delegate } \\
\text { responsibilities was paramount in project's } \\
\text { success. }\end{array}$ & $\begin{array}{l}\text { Individual's level of professionalism and } \\
\text { maturity was exemplary. Individual was able to } \\
\text { foster a positive professional relationship with } \\
\text { others outside the team who were involved in } \\
\text { the project, which added greatly to the success } \\
\text { of the project. }\end{array}$ \\
\hline
\end{tabular}

Proceedings of the 2003 American Society for Engineering Education Annual Conference \& Exposition Copyright $\odot$ 2003, American Society for Engineering Education 


\begin{tabular}{|c|c|c|c|c|c|c|}
\hline & & \multicolumn{3}{|c|}{ Table 2. Overall Program Rubric } & \multirow[b]{2}{*}{ Results } & \multirow[b]{2}{*}{ System } \\
\hline & $\begin{array}{l}\text { Educational } \\
\text { Objectives }\end{array}$ & Constituents & Processes & Outcomes Assessment & & \\
\hline 1 & Not well defined & Informal contact & $\begin{array}{l}\text { Few, if any processes } \\
\text { defined and documented }\end{array}$ & Limited to ad hoc efforts & Anecdotal & None evident \\
\hline 2 & $\begin{array}{l}\text { Broadly defined and } \\
\text { documented: clearly tied } \\
\text { to mission; evidence of } \\
\text { constituent input }\end{array}$ & $\begin{array}{l}\text { Somewhat involved in } \\
\text { defining objectives } \\
\text { and desired } \\
\text { outcomes, and } \\
\text { assessment }\end{array}$ & $\begin{array}{l}\text { Some major processes } \\
\text { defined and documented; } \\
\text { clearly tied to mission and } \\
\text { program objectives }\end{array}$ & $\begin{array}{l}\text { Some outcomes defined } \\
\text { and improved in systematic } \\
\text { manner; problems } \\
\text { recognized and corrected }\end{array}$ & $\begin{array}{l}\text { Satisfactory outcomes; } \\
\text { some evidence of } \\
\text { positive trends in } \\
\text { areas deployed }\end{array}$ & $\begin{array}{l}\text { Early stages; } \\
\text { partial } \\
\text { deployment } \\
\text { within the } \\
\text { program and } \\
\text { college }\end{array}$ \\
\hline 3 & $\begin{array}{l}\text { Comprehensive; defined, } \\
\text { documented' and } \\
\text { measurable; clearly tied to } \\
\text { mission and constituent } \\
\text { needs }\end{array}$ & $\begin{array}{l}\text { Clearly involved in } \\
\text { defining objectives } \\
\text { and desired } \\
\text { outcomes, and } \\
\text { assessment; evidence } \\
\text { of some sustained } \\
\text { strategic partnerships }\end{array}$ & $\begin{array}{l}\text { Processes for all major } \\
\text { elements of criteria } \\
\text { defined, documented, and } \\
\text { controlled; clearly tied to } \\
\text { mission, program } \\
\text { objectives, and } \\
\text { constituent needs }\end{array}$ & $\begin{array}{l}\text { All major outcomes } \\
\text { defined; systematic } \\
\text { evaluation and process } \\
\text { improvement in place; } \\
\text { problems anticipated and } \\
\text { prevented }\end{array}$ & $\begin{array}{l}\text { Good outcomes; } \\
\text { positive trends in } \\
\text { several major areas; } \\
\text { some evidence that } \\
\text { results caused by } \\
\text { systematic approach }\end{array}$ & $\begin{array}{l}\text { In place; } \\
\text { deployed } \\
\text { throughout the } \\
\text { program and } \\
\text { college; driven } \\
\text { by mission } \\
\text { and objectives }\end{array}$ \\
\hline 4 & $\begin{array}{l}\text { Comprehensive; defined, } \\
\text { documented and } \\
\text { measurable; clearly tied to } \\
\text { mission; responsive to } \\
\text { constituent needs; } \\
\text { systematically reviewed } \\
\text { and updated }\end{array}$ & $\begin{array}{l}\text { High degree of } \\
\text { involvement in } \\
\text { defining objectives } \\
\text { and desired } \\
\text { outcomes; evidence } \\
\text { of many sustained } \\
\text { strategic partnerships } \\
\text { in all constituent } \\
\text { groups }\end{array}$ & $\begin{array}{l}\text { Processes for all } \\
\text { elements of criteria are } \\
\text { quantitatively understood } \\
\text { and controlled; clearly } \\
\text { tied to mission, program } \\
\text { objectives, and } \\
\text { constituent needs }\end{array}$ & $\begin{array}{l}\text { All outcomes defined; } \\
\text { systematic evaluation and } \\
\text { process improvement in } \\
\text { place; many support areas } \\
\text { involved; sources of } \\
\text { problems understood and } \\
\text { eliminated }\end{array}$ & $\begin{array}{l}\text { Excellent outcomes; } \\
\text { positive trends in most } \\
\text { areas; evidence that } \\
\text { results caused by } \\
\text { systematic approach }\end{array}$ & $\begin{array}{l}\text { Integrated; } \\
\text { deployed } \\
\text { throughout the } \\
\text { program, } \\
\text { college and } \\
\text { support areas; } \\
\text { driven by } \\
\text { mission and } \\
\text { objectives }\end{array}$ \\
\hline 5 & $\begin{array}{l}\text { Comprehensive; defined } \\
\text { documented, measurable } \\
\text { and flexible; clearly tied to } \\
\text { mission; readily adaptable } \\
\text { to meet constituent needs; } \\
\text { systematically reviewed } \\
\text { and updated }\end{array}$ & $\begin{array}{l}\text { High degree of } \\
\text { involvement in } \\
\text { defining objectives } \\
\text { and desired } \\
\text { outcomes, } \\
\text { assessment; and } \\
\text { improvement cycles; } \\
\text { sustained evidence of } \\
\text { strategic partnership } \\
\text { with all key } \\
\text { constituents }\end{array}$ & $\begin{array}{l}\text { Processes for all } \\
\text { elements of criteria are } \\
\text { quantitatively understood } \\
\text { and controlled; clearly } \\
\text { tied to mission; program } \\
\text { objectives, and } \\
\text { constituent needs; seen } \\
\text { as benchmarks by other } \\
\text { institutions }\end{array}$ & $\begin{array}{l}\text { All outcomes defined; } \\
\text { systematic evaluation and } \\
\text { process improvement in } \\
\text { place; all support areas } \\
\text { involved; common sources } \\
\text { of problems understood } \\
\text { and eliminated }\end{array}$ & $\begin{array}{l}\text { World-class } \\
\text { outcomes; sustained } \\
\text { results; results clearly } \\
\text { caused by systematic } \\
\text { approach }\end{array}$ & $\begin{array}{l}\text { Sound, highly } \\
\text { integrated } \\
\text { system; } \\
\text { deployed } \\
\text { throughout the } \\
\text { program, } \\
\text { college, and } \\
\text { institution; } \\
\text { driven by } \\
\text { mission and } \\
\text { objectives }\end{array}$ \\
\hline
\end{tabular}

Proceedings of the 2003 American Society for Engineering Education Annual Conference \& Exposition Copyright $@$ 2003, American Society for Engineering Education 


\section{Assessment and evaluation tools}

Before you get started on any academic program, but particularly one that is cross disciplinary, we strongly suggest you perform readiness assessment. While many institutions promote cross disciplinary programs, they are usually graduate research programs. Universities are organized in functional silos of colleges, departments and even sub disciplines. Budgets, promotions and other rewards are conducted from the top down through these silos. Matrix management and project management, particularly at the undergraduate level, are often unknown concepts. As a result, decisions are often locally optimized to the detriment of cross-disciplinary programs.

One of the outcomes of our federal funding is the development of institutional readiness assessment tools for IPD implementation. These are expected to be completed by the end of August, 2003. Key to the assessment will be discovery and recognition of specific examples of cross disciplinary activities. We suggest you look for examples of cross-disciplinary programs and if they do exist, then go talk to the people who were involved and learn from their implementation. Otherwise, start the planning process.

\section{Good people will make it happen}

The final lesson is the same as the first mentioned above. Good people will make things happen. Always surround yourself with upbeat, "can do" people, people who will not focus on the 1000 ways something will fail, but who will work with you to find the one or two ways you might succeed. Be of constant focus and consistency of purpose while treating the people around you with honor and respect. Each day give them reasons to choose to come to work with you, on your projects, your programs.

\section{Summary and Conclusion}

Since 1995 a group of dedicated administrators, faculty, staff, students and alumni have been engaged in transforming the educational environment at Lehigh University. The Integrated Product Development Program, the Integrated Business and Engineering Program and the Design Arts Programs are three examples of programs that have redefined and reenergized education across all three undergraduate colleges. We have learned valuable lessons in the process, these include: 1) planning works, 2) cross disciplinary teams make it work, 3 ) always surround yourself with team member who are action oriented, trustworthy and honorable, 4) always do whatever it takes to keep the administration on your team, 5) continuously improve by critical self and external assessment, 6) engage a broad base of support from alumni and industrial friends, 7) seek financial support and build on it, 8) start with small pilots and build on your successes, 9) be you own public relations department by staying focused celebrating successes and learning from mistakes, 10) surround yourself with good, positive thinking people.

In the next four years all three programs, IPD, IBE and Design Arts, will be at steady state and we plan to expand into graduate programs and related areas of research. By fall 2003 a new facility will be in place supporting the faculty, staff and students involved in these programs. We plan to continue the $20 \%$ annual growth and we plan to manage that growth through cooperation, coordination and communication across the many disciplines that choose to be engaged in the development of our entrepreneurial environment. 


\section{References:}

1. Galbraith, Jay R., Designing Complex Organizations, Addison-Wesley, Reading Mass, 1973.

2. Andreasen, M Myrup and Lars Hein, Integrated Product Development, Springer-Verlag, New York, 1987.

3. Smith, Preston G., and Donald G. Reinertsen, Developing Products in Half the Time, Van Norstrand Reinhold, New York, 1991.

4. Wheelwright, Stephen C., and Kim B. Clark, Revolutionizing Product Development: Quantum Leaps in Speed, Efficiency, and Quality, The Free Press, New York, 1992

5. Katzenbach, Jon R., and Douglas K Smith, The Wisdom of Teams: Creating the High Performance Organization, Harvard Business School Press, Boston 1993.

6. Galbraith, Jay R., Competing with Flexible Lateral Organizations, second edition, AddisonWesley, Reading, Mass, 1994.

7. Kostner, Jaclyn, Virtual Leadership: Secrets from the Round Table for the Multi-site Manager, Warner Books, New York, 1994.

8. Ulrich, Karl, T., and Steven D. Eppinger, Product Design and Development, second edition, Irwin, McGraw-Hill, New York, 1999.

9. Todd A. Watkins, John B. Ochs and Berrisford W. Boothe, "Integrating Design Arts, Engineering and Business Curricula through Multidisciplinary product Design Projects," Proceeding from the Second Annual NCIIA Conference, Washington DC, March 13-15, 1998.

10. Ochs, John B. and Watkins Todd A. "Demonstration Project Linking Academic Entrepreneurial Courses with Dislocated and New Entrant Workers for Self Employment and New Company Start-ups,” Department of Labor grant, Jan 2001.

11. Ochs, John B., and Boothe, Berrisford, W., "Congressional Grant from the Department of Education to Lehigh University," Grant \# P116Z000033, Jan 2000.

12. Ochs, John B., NASA/CAPE IPD Projects, subcontract to grant \# 991182, March 2000.

13. Ochs, John B., and Wolkoff, Regina L., "Global collaboration," The Journal of British Association for Open Learning, Issue 51, Jan 2000.

14. Van Kollenburg, Peter, A, and Ochs, John B., "Collaborative Engineering Experiences," Proceedings of the $22^{\text {nd }}$ SEED Annual Design Conference and $7^{\text {th }}$ National Conference on Product Design Education, University of Sussex, Brighton, UK, September, 2000

15. Ochs, John B., Watkins, Todd A., and Boothe, Berrisford W., "Creating a Truly multidisciplinary Entrepreneurial Educational Environment," Journal of Engineering Education, October 2001, pp 577 to 583.

16. Ochs, John, B, Watkins, Todd A, and Boothe, Berrisford W., "Cultivating an Entrepreneurial Spirit through Cross-disciplinary Student teams in Freshman Projects Course," Proceedings of the American Society of Engineering Education Conference, Montreal Canada, June 2002.

17. Ochs, John B, Watkins, Todd A. and Boothe, Berrisford, W., "Attracting Under Represented Students to Engineering through Career Awareness Programs (CAP)," Abstract. Proceedings of the American Society of Engineering Education Conference, Montreal Canada, June 2002.

Proceedings of the 2003 American Society for Engineering Education Annual Conference \& Exposition Copyright (C 2003, American Society for Engineering Education 


\section{JOHN B. OCHS}

Professor John B. Ochs has been teaching engineering design at Lehigh University since 1979. Since 1995 he has worked with an interdisciplinary team of faculty and students from business and arts to establish undergraduate and graduate curricula focusing on experiential learning through industry projects. The award winning IPD program is now in its $6^{\text {th }}$ year with over 150 industrysponsored projects and over 750 student participants. In addition to the IPD program Professor Ochs is the founder and director of the Mechanical Engineering and Mechanics Computer Aided Design Lab and co-director of the Dravo Design and Prototype Shop. Professor Ochs teaches and does research in Computer Graphics for Engineering Design, Geometric Dimensions and Tolerances, Manufacturing, and many types of computer graphics modeling and simulations. Professor Ochs has been involved in several startups, two of which have been moderately successful. He is a member of the Acoustical Society of America, the Society of Manufacturing Engineers, the American Society of Mechanical Engineers and Phi Kappa Phi.

\section{TODD A. WATKINS}

Todd A. Watkins is the Faculty Fellow to the Provost and Associate Professor in the College of Business \& Economics at Lehigh University. Professor Watkins holds Ph.D. and M.P.P. degrees from Harvard University and a B.S. from the University of Rochester. He previously worked in optical design and optic manufacturing engineering at Eastman Kodak. His research involves the economics of innovation, defense industry \& dual-use manufacturing, and technology policy. Teaching areas encompass the role of technology in trade \& economic growth; as well as managerial economics; and new product development. As faculty fellow, he directs Lehigh's Venture initiative, which promotes innovation, inquiry-based, experimental curriculum throughout the university. He founded and serves as co-director of Lehigh's Community Research and Policy Service (Lehigh COPRS), and was one of the founders of Lehigh's IPD Program, national winner of the ASME Curriculum Innovation Award. Watkins also won the 1999 Outstanding Instructor award from the National Technology University, for his teaching via distance learning.

\section{DREW SNYDER}

Drew Snyder is an adjunct professor of design arts in the Department of Art and Architecture within the College of Arts and Science at Lehigh University. Drew has training in industrial design, fine art, and computer graphics. He has been a visiting lecturer at Lehigh University for the past 5 years. During his time at Lehigh, he has been a pivotal player in the incorporation of ergonomics and aesthetics into the Integrated Product Development (IPD) curriculum, serving as a lecturer, advisor, and conducting workshops in design training from students enrolled in IPD courses and in Integrated Business and Engineering (IBE) Program. Drew has also been a key contributor to the development of a new design arts majors at Lehigh. The Design Arts Program strives to incorporate the spirit of IPD into a multidiscipline sequence of courses in industrial design, graphic design, web design, and computer graphics. Snyder has his undergraduate degree in Industrial Design from Carnegie Mellon University and is currently working on towards an advanced degree in digital imaging and design at New York University.

Proceedings of the 2003 American Society for Engineering Education Annual Conference \& Exposition Copyright (C 2003, American Society for Engineering Education 